\title{
Testicular volume in adult patients undergoing cryptorchidism surgery in childhood, and impact on paternity
}

\author{
R. Fernández Atuan ${ }^{1,2}$, Y. González Ruiz' ${ }^{1,2}$, P. Salcedo Arroyo ${ }^{1}$, P. Vargova1, P. Bragagnini Rodríguez ${ }^{1,2}$, M. Ruiz de Temiño ${ }^{1,2}$
}

${ }^{1}$ Pediatric Surgery Department. Miguel Servet University Hospital. Zaragoza (Spain). ${ }^{2}$ Healthcare Research Institute of Aragon (IIS Aragón). (Spain).

\begin{abstract}
Objective. To determine the impact of orchiopexy on testicular volume. To determine whether age at surgery impacts testicular volume. To determine whether paternity is associated with testicular volume.

Methods. Patients born between 1961 and 1985 who had undergone cryptorchidism surgery at the Pediatric Surgery Department of Miguel Servet University Hospital were included. Testis location and macroscopic appearance data were collected. Control testicular ultrasonographies and paternity surveys were carried out. Initially, the study was descriptive, and subsequently, inferential.

Results. Ultrasonography was performed in 216 testicular units a mean of 14.9 years following surgery, whereas the paternity survey was conducted among 157 respondents a mean of 41.9 years following surgery. There were significant differences $(p=0.0038)$ in testicular volume distribution according to epididymal dissociation. There was a linear correlation between older age at surgery and lower testicular volume, but without statistical significance. Significant differences $(\mathrm{p}=<0.0001)$ in testicular volume according to groups - operated and non-operated -, as well as between unilateral and bilateral cases, were found. No differences in paternity rates according to testicular volume were noted.

Conclusion. Operated testes have lower volumes than normally descended testes. Older age at surgery may contribute to lower final volumes. Testes with full epididymal-testicular dissociation have lower total volumes. No relation between testicular volume and paternity rates was found. Further long-term studies are required.
\end{abstract}

KeY Words: Undescended testis; Cryptorchidism; Testicular volume; Orchiopexy.

DOI: $10.54847 /$ cp. 2022.01 .15

Corresponding author: Dr. Rafael Fernández Atuan.

E-mail address: raferat@gmail.com

This work was presented as a communication at the $58^{\text {th }}$ Congress of the Spanish Pediatric Surgery Society held in Vigo in 2019.

This work was presented as a poster at the $20^{\text {th }}$ Congress of the European

Pediatric Surgeons' Association held in Belgrade in 2019
VOLUMEN TESTICULAR EN PACIENTES ADULTOS OPERADOS DE CRIPTORQUIDIA EN EDAD INFANTIL Y SU EFECTO SOBRE LA PATERNIDAD

\section{RESUMEN}

Objetivos. Determinar el efecto de la orquidopexia sobre el volumen testicular. Determinar si la edad de intervención afecta el volumen testicular. Determinar si la paternidad se asocia al volumen testicular.

Métodos. Pacientes nacidos entre los años 1961 y 1985, intervenidos de criptorquidia por el Servicio de Cirugía Pediátrica del Hospital Universitario Miguel Servet, tomando datos de la localización del teste y aspecto macroscópico. Se realizan ecografías testiculares de control y encuestas de paternidad. Realizamos un estudio inicial descriptivo y posteriormente inferencial.

Resultados. La ecografía se realizó con una media de 14,9 años postoperatorios en 216 unidades testiculares y la encuesta de paternidad con una media 41,9 años postoperatorios a 157 participantes. Existen diferencias significativas $(\mathrm{p}=0,0038)$ en la distribución del volumen testicular según disyunción del epidídimo. Hay correlación lineal entre mayor edad de tratamiento quirúrgico y menor volumen testicular sin llegar a significancia estadística. Se observan diferencias significativas ( $p=<0,0001$ ) en el volumen testicular según grupos de operados y no operados, como también entre los unilaterales y los bilaterales. No se observan diferencias en índices de paternidad según volumen testicular.

Conclusión. El teste intervenido presenta un volumen testicular menor que el teste de descenso normal. Una mayor edad de tratamiento quirúrgico puede contribuir a un menor volumen final del teste. Los testículos con disyunción epidídimo testicular completa, tienen menor volumen total. No observamos relación entre el volumen testicular y índices de paternidad. Más estudios a largo plazo son necesarios.

Palabras Clave: Testículo no descendido; Criptorquidia; Volumen testicular; Orquidopexia. 


\section{INTRODUCTION}

According to Hutson ${ }^{(1)}$, cryptorchidism refers to the absence of the testis within the scrotal sac. When the testis is palpable, it cannot be manipulated at the bottom of the scrotal sac unless tension is applied on the spermatic cord, and it usually goes back to its abnormal position when tension is released.

Cryptorchidism is the most frequent congenital abnormality in children. In full-term newborns, it has an incidence of 3-5\% (1-3). In 70\% of cases, testes spontaneously descend to the sac within the first year as they grow. At 1 year of age, prevalence is around $1 \%$, and the proportion remains the same in adulthood ${ }^{(3,4)}$. Schneuer found an incidence of 9.6 operated testes in 1,000 live births ${ }^{(5)}$.

Testes in abnormal locations are subject to histological disorders. According to Hadziselimovic's studies, there is a decrease in the number of gonocytes to $\mathrm{AD}$ spermatogonias (dark, type A ones), which entails spermatogenesis disorders $^{(6)}$. In a prospective study, Verkauskas reported that 9-15\% of patients with unilateral involvement and up to $46 \%$ of patients with bilateral involvement develop oligospermia or azoospermia ${ }^{(7)}$. Other histological disorders include seminiferous tubule fibrosis, Sertoli and Leydig cell disorders, basement membrane thickening, interstitial edema, and increased mastocytes in the testicular parenchyma ${ }^{(8-10)}$.

Suprascrotal testis can occur in congenital cryptorchidism, but also in acquired cryptorchidism and retractile testis. According to Hack, acquired cryptorchidism has a prevalence of $2.2 \%$ in the 9 -year-old population, and $1.1 \%$ in the 13-year-old population. In a study, Guven found that $45 \%$ of late orchiopexies occur in patients with previous history of normal testicular descent, whereas Van der Plas found that up to $66 \%$ of late orchiopexies had previous history of normal descent in clinical records ${ }^{(11-13)}$. In a review of cryptorchidism and fertility, Virtanen stated that histological disorders associated with acquired and congenital cryptorchidism are the same ${ }^{(14)}$. Suprascrotal testis has been clearly demonstrated to be associated with histological disorders, which clinically manifest as spermiogram disorders and decreased testicular volume. Our objective was to assess the long-term impact of cryptorchidism on final testicular volume, and also the likelihood of testes compensating growth. We also aimed to determine whether these volume disorders were correlated with paternity disorders. Our hypothesis was that testes in an abnormal position have permanently reduced volumes and functioning.

\section{MATERIALS AND METHODS}

\section{Scope and study patients}

Patients born between 1961 and 1985 who had undergone cryptorchidism surgery at the Pediatric Surgery Department of Miguel Servet University Hospital, and who had participated in a fertility study in 1999, were included. Clinical, surgical, analytical, and pathological data of these patients since childhood were available to us. We also had data on postoperative control testicular ultrasonographies. Testis size was ultrasound-measured and calculated using an ellipsoid formula, where a 0.52 constant was multiplied by the result of multiplying length by width squared $(0.52$ $\mathrm{x}\left[\mathrm{L} \mathrm{x} \mathrm{W}^{2}\right]$ ). Volumes were expressed in cubic centimeters.

A survey was sent by post to 258 patients from the aforementioned database who had undergone cryptorchidism surgery at our department. 97 patients responded. The remaining 161 patients were contacted by phone, with 60 of them agreeing to participate in a telephone survey. A total of 157 patients $(60.85 \%)$ were recruited.

\section{Design and statistical methodology}

A retrospective cohort study comparing paternity rates in a group of former cryptorchidism patients with paternity rates in an equivalent group without cryptorchidism by means of a survey was carried out. The second part involved a statistical analysis of the testicular ultrasonographies performed in the adults who had undergone cryptorchidism surgery vs. the data retrieved in the survey.

In the descriptive analysis of data, qualitative variables were presented as the frequency distribution of percentages in each category. The quantitative variables studied were explored using Kolmogorov-Smirnov conformity test $-\mathrm{a}$ normal distribution goodness-of-fit test.

\section{Bivariate analysis. Comparison of variables}

The association of factors was assessed using hypothesis testing studies. Impacts were considered significant if $\mathrm{p}$ values were $<0.05$ and two-tailed.

For statistical analysis purposes, the SPSS v. 18.0.0 software was used. Statistical support was provided by the Department of Methodological Support from Aragon's Institute of Health Sciences.

\section{Ethical considerations}

The authors obtained informed consent from all participants. The study was approved by Aragon's Research Ethics Committee (CEICA), with registration number CP12/2014.

These data were featured in Rafael Fernández Atuan's $\mathrm{PhD}$, presented in Zaragoza (Spain) in 2017, and entitled "Study of fertility in patients undergoing cryptorchidism surgery."

\section{RESULTS}

Respondents were aged 31-55 years old, with a mean age of 41.9 years. Testicular ultrasonographies were performed in 216 testicular units 1-20 years following orchiopexy (mean: 14.9 years). 


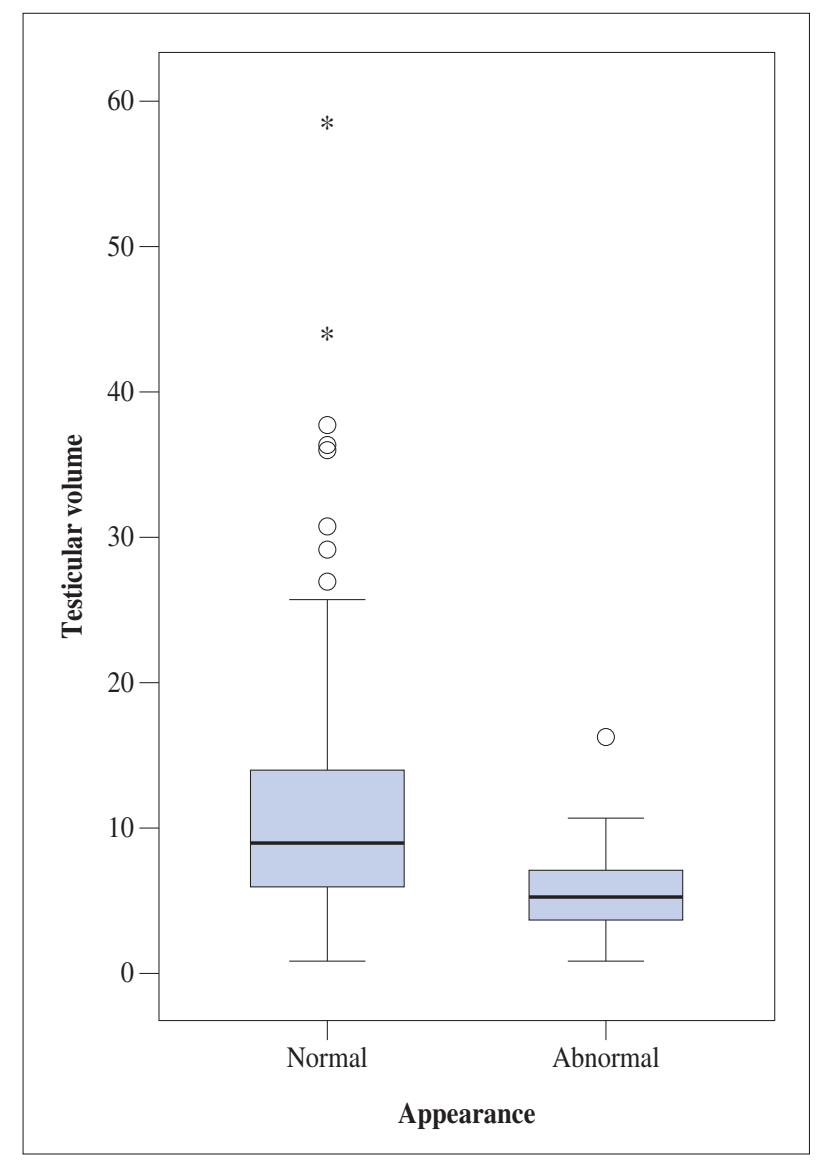

Figure 1. Testicular volume vs. appearance of the epididymal-testicular fusion. Statistically significant differences in testicular volume distribution according to testis appearance were found (testicular volume expressed in cubic centimeters).

120 patients $(76.43 \%)$ had unilateral involvement, whereas 37 patients $(23.57 \%)$ had bilateral involvement. $14.4 \%$ of the testes undergoing surgery had an abnormal appearance at surgery, with abnormality being defined as full epididymal-testicular dissociation. A statistically significant difference $(\mathrm{p}<0.038)$ in testicular volume distribution according to testis appearance was noted (Fig. 1).

Mean age at surgery was 6.2 years. When analyzing age at surgery vs. testicular volume, a linear correlation between age at surgery and lower testicular volume was found in the total population. However, this correlation was not statistically significant in our study (Fig. 2, Table I).

When analyzing testicular volumes of operated vs. non-operated contralateral testes, statistically significant differences in testicular volume distribution according to groups of operated (undescended) and non-operated (contralateral) testes were observed (Fig. 3).

When comparing testicular volume in patients with unilateral cryptorchidism with testicular volume in patients with bilateral cryptorchidism, statistically significant dif-

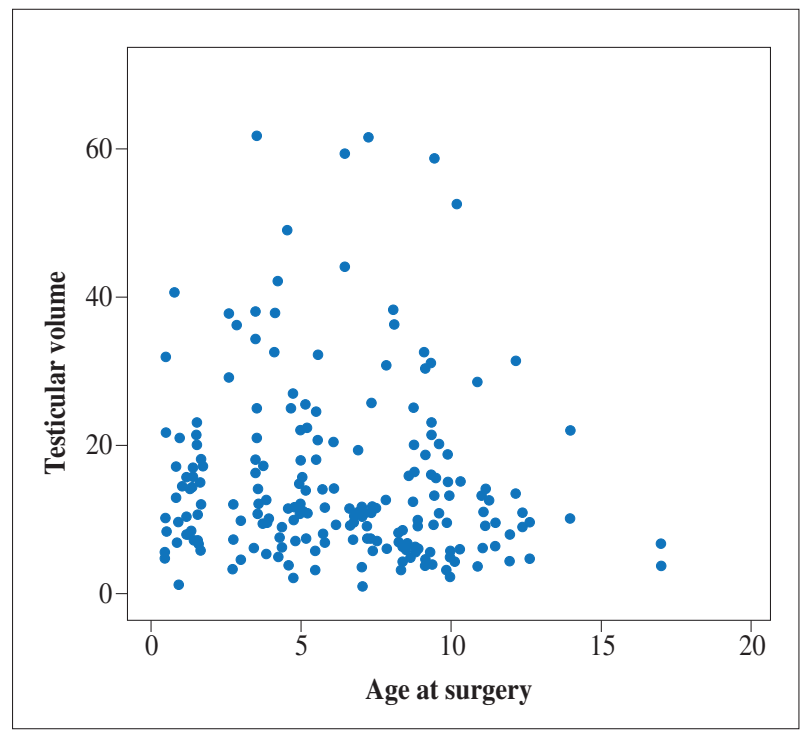

Figure 2. Linear analysis of age at surgery vs. testicular volume.

Table I. Analysis of age at surgery and testicular volume.

\begin{tabular}{|c|c|c|c|c|}
\hline & & \multicolumn{3}{|c|}{ Testicular volume } \\
\hline & & $\begin{array}{c}\text { Total } \\
\text { population }\end{array}$ & Contralateral & Operated \\
\hline \multirow{2}{*}{$\begin{array}{l}\text { Age at } \\
\text { surgery }\end{array}$} & $\begin{array}{c}\text { Pearson } \\
\text { correlation }\end{array}$ & -0.11 & -0.14 & -0.02 \\
\hline & p-value & $>0.05$ & $>0.05$ & $>0.05$ \\
\hline \multicolumn{5}{|c|}{$\begin{array}{l}\text { A negative Pearson correlation was found. However, linear correlation } \\
\text { between age at surgery and testicular volume in the total population } \\
\text { was not statistically significant in our study (testicular volume expressed } \\
\text { in cubic centimeters, and age expressed in years). }\end{array}$} \\
\hline
\end{tabular}

ferences in testicular volume distribution according to unilateral and bilateral involvement groups were found. Patients with unilateral involvement had larger testicular volumes (Fig. 4).

In patients undergoing surgery, no statistical association between testicular volume and paternity rates was noted (Table II). In our study, time to pregnancy was 10.6 months for patients in the unilateral involvement group, 15.8 months for patients in the bilateral involvement group, and 8.1 months for patients in the control group.

Of the total of patients, only 19 reported having required a fertility treatment. When asked about the type of treatment used, 18 of them responded, and according to their replies, $44.4 \%$ used IVF, $27.8 \%$ used male hormones, and $11.1 \%$ used intracytoplasmic sperm injection (ICSI). In the remaining $16.7 \%$ of patients, treatment was administered to their female partner only. 


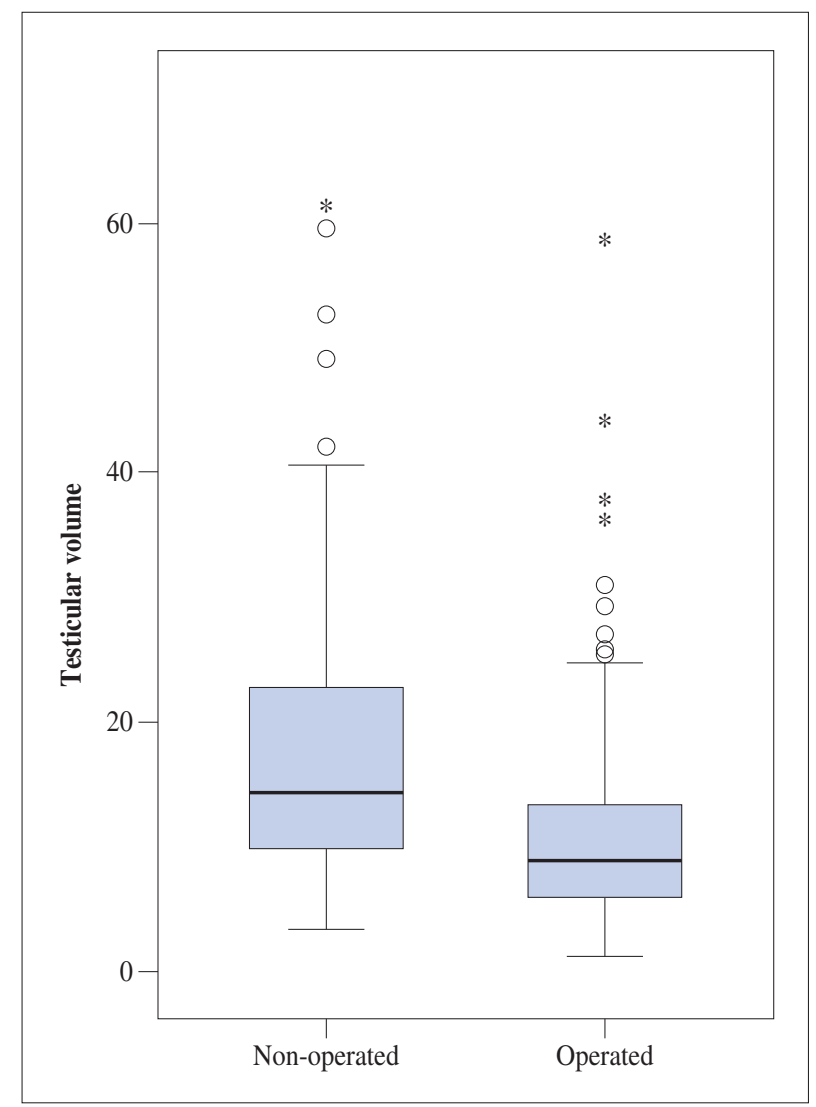

Figure 3. Testicular volume of operated $v s$. non-operated testes. Statistically significant differences in testicular volume distribution according to groups of operated (undescended) and non-operated (contralateral) testes were found (testicular volume expressed in cubic centimeters).

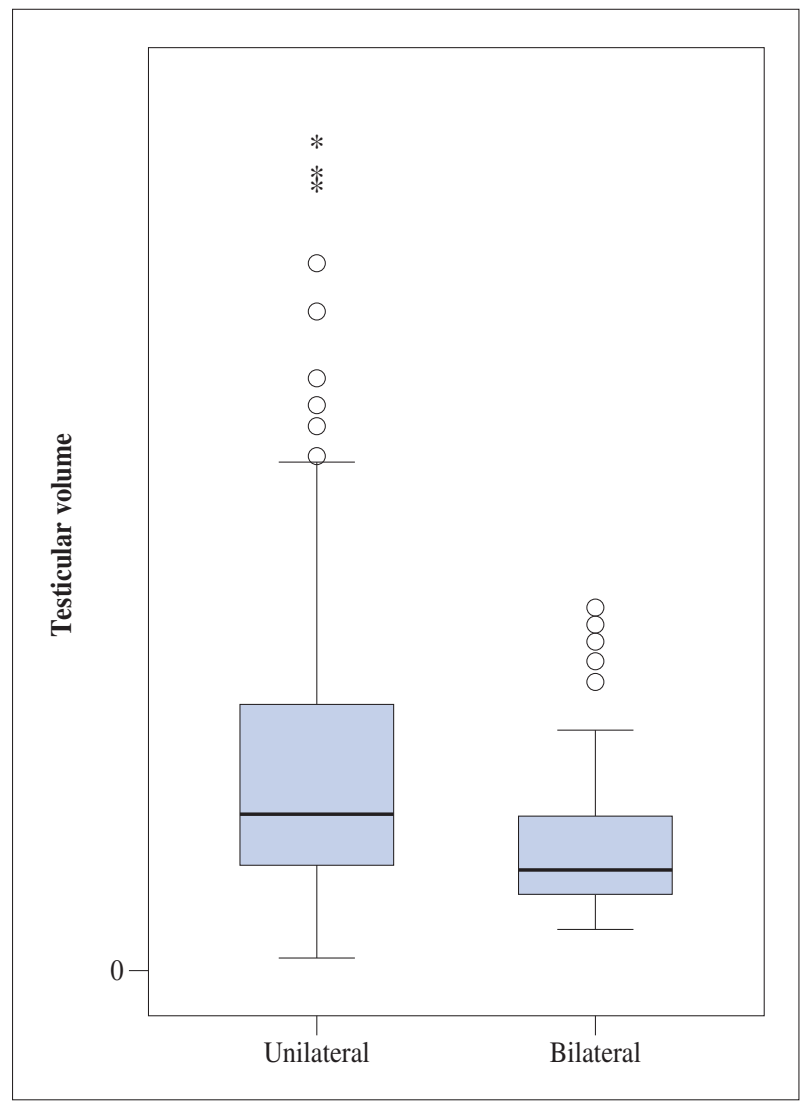

Figure 4. Testicular volume in unilateral vs. bilateral involvement. Patients with unilateral involvement have greater testicular volume (testicular volume expressed in cubic centimeters).

Table II. Analysis of testicular volume and paternity rates.

\begin{tabular}{|c|c|c|c|c|c|}
\hline & & Total population & No children & Children & $p$-value \\
\hline \multirow{2}{*}{ Volume of operated testes } & Mean & 12.07 & 12.10 & 12.25 & \multirow{2}{*}{$>0.05$} \\
\hline & $\mathrm{SD}$ & 10.45 & 11.60 & 9.30 & \\
\hline \multirow{2}{*}{ Volume of non-operated testes } & Mean & 18.78 & 18.51 & 19.34 & \multirow{2}{*}{$>0.05$} \\
\hline & SD & 12.91 & 11.70 & 14.36 & \\
\hline
\end{tabular}

\section{DISCUSSION}

In our study, testes were identified as normal or abnormal according to clinical characteristics at surgery. Clinical characteristics did not only refer to the macroscopic appearance of the testicular parenchyma, but also, importantly, to the appearance of the epididymis-testis complex. The epididymis should be fully attached to the testicular parenchyma. However, in this study, as a result of per- ceptions among surgeons being variable, testes with full epididymal-testicular dissociation only were regarded as abnormal. They accounted for $14.4 \%$ of the total. A statistically significant difference between abnormal testes and testicular volume was found $(\mathrm{p}=0.038)$. In a study, Kim assessed testicular appearance by comparing patients with cryptorchidism and hydrocele, and observed full dissociation in $12.3 \%$ of patients ${ }^{(15)}$. This study also found that all intra-abdominal testes have epididymal disorders, and 
that the higher the testis is located, the greater epididymis-testicular dissociation will be ${ }^{(15)}$. No articles comparing epididymal condition vs. testicular volume were found.

Age at surgery, testicular volume, and association with fertility have been thoroughly studied for many years. In our study, a negative correlation between testicular volume and age at surgery was found, but without statistical significance. It should be highlighted that ultrasound testicular control was carried out 14.9 years following surgery, which means the operated testes may have compensated and grown. Mean age at surgery was 6.2 years. This is a bit too late as per today's standards, which establish age at surgery should range from 12 to 30 months. Our result is consistent with Taskinen's, who found a lower testicular volume in patients undergoing surgery at 4 years of age than in patients undergoing surgery at an older age, without statistical significance ${ }^{(16)}$. Other researchers have found significant differences in terms of testicular volume between patients with undescended testes undergoing surgery at 9 months of age and patients with undescended testes undergoing surgery at 3 years of age, with a follow-up that lasted until 5 years of age in both groups - which means follow-up time allowing operated testes to recover was different ${ }^{(17)}$. With a follow-up time of 6.9 months, Durell found that up to $20 \%$ of testes compensate growth and may reach the same size as contralateral ones when orchiopexy is performed at the age of 12 months approximately, with testes being subjectively assessed by the researchers ${ }^{(18)}$. Testicular atrophy has been reported to be greater in patients undergoing surgery after 13 months of age than in patients undergoing surgery before 13 months of age ${ }^{(19)}$. Carson conducted a regression analysis comparing age at surgery and postoperative testicular atrophy, adjusted for testicular location, and found no significant differences, suggesting that the impact of extra-abdominal location is lower than that of age at surgery ${ }^{(16,19)}$. It should be noted that age at surgery currently ranges from 13 to 30 months of age in our surgical department.

No significant correlation between testicular volume and paternity rates was found. In a study with 166 patients undergoing unilateral orchiopexy, Lee did not find any differences in paternity rates according to testicular volume. The study was based on the surgical team's perception of testis size ${ }^{(20)}$. Testicular volume is seemingly not correlated with germ cell count, which means it cannot be used as a reliable parameter to predict reproductive capacity. However, volume is associated with a clear deterioration of sperm quality ${ }^{(21)}$. Ates found that the volume of the descended testis was the only variable associated with sperm quality in adult patients ${ }^{(20-22)}$. In the case of bilateral cryptorchidism, no statistically significant differences in terms of paternity rates between patients with bilateral cryptorchidism and patients in the control group were noted. Similar results have been reported in other studies, although this was seemingly due to the low number of patients with bilateral cryptorchidism included ${ }^{(23)}$. In our case, there were 37 patients with bilateral involvement, while Van Brakel's study consisted of 7 patients ${ }^{(23)}$. Studies with a larger cohort of patients with bilateral cryptorchidism do report a significant reduction in paternity rates. Approximately $65.3 \%$ of patients with bilateral involvement who wanted to have a baby succeeded in doing so, which is lower than the proportion of patients with unilateral cryptorchidism or patients in the control group, the difference being statistically significant ${ }^{(24)}$. In patients with bilateral involvement, $76 \%$ of those who underwent orchiopexy earlier (between 10 months and 3 years of age) had a normal spermatozoon count $v s .26 \%$ of patients undergoing surgery later ${ }^{24,25)}$. According to a recent review of cryptorchidism management, $75 \%$ of patients with bilateral involvement have oligospermia, and $42 \%$ have azoospermia ${ }^{(26)}$.

\section{CONFLICTS OF INTEREST AND STUDY LIMITATIONS}

The authors of this study declare no conflicts of interest. Limitations lie in the study's retrospective nature and the fact patients with congenital cryptorchidism and acquired cryptorchidism were included as a result of data collection.

\section{CONCLUSIONS}

Operated testes are inevitably impacted in their final growth as compared to contralateral descended testes and testes in the normal population. This impact is correlated with age at surgery in our study and others, but in our case, no statistical significance was achieved.

Patients with bilateral involvement and epididymal-testicular dissociation have lower growth compensation abilities, and therefore, lower testicular volumes. Patients with bilateral involvement required a longer time to have children.

No association between testicular volume and paternity rates was found, which means testicular volume is seemingly not a reliable method to determine fertility. Time to pregnancy was longer in patients with bilateral involvement.

Further studies with a long-term follow-up are required to corroborate results.

\section{REFERENCES}

1. Hutson JM, Balic A, Nation T, Southwell B. Cryptorchidism. Semin Pediatr Surg. 2010; 19(3): 215-24.

2. Virtanen HE, Bjerknes R, Cortes D, Jørgensen N, Rajpert-De Meyts E, Thorsson AV, et al. Cryptorchidism: classification, prevalence and long-term consequences. Acta Paediatr. 2007; 96(5): 611-6. 
3. Barthold JS, González R. The epidemiology of congenital cryptorchidism, testicular ascent and orchiopexy. J Urol. 2003; 170(6 Pt 1): 2396-401.

4. Holland AJ, Nassar N, Schneuer FJ. Undescended testes: an update. Curr Opin Pediatr. 2016; 28(3): 388-94.

5. Schneuer FJ, Holland AJ, Pereira G, Jamieson S, Bower C, Nassar N. Age at Surgery and Outcomes of an Undescended Testis. Pediatrics. 2016; 137(2): e20152768.

6. Hadziselimovic F, Hocht B, Herzog B, Buser MW. Infertility in cryptorchidism is linked to the stage of germ cell development at orchidopexy. Horm Res. 2007; 68(1): 46-52.

7. Verkauskas G, Malcius D, Eidukaite A, Vilimas J, Dasevicius D, Bilius V, et al. Prospective study of histological and endocrine parameters of gonadal function in boys with cryptorchidism. J Pediatr Urol. 2016; 12(4): 238.e1-6.

8. Acikgoz A, Asci R, Aydin O, Çavus H, Donmez G, Buyukalpelli $\mathrm{R}$. The role of ketotifen in the prevention of testicular damage in rats with experimental unilateral undescended testes. Drug Des Devel Ther. 2014; 8: 2089-97.

9. Li R, Thorup J, Sun C, Cortes D, Southwell B, Hutson J. Immunofluorescent analysis of testicular biopsies with germ cell and Sertoli cell markers shows significant MVH negative germ cell depletion with older age at orchiopexy. J Urol. 2014; 191(2): 458-64.

10. Koni A, Ozseker HS, Arpali E, Kilinc E, Dogan HS, Akyol A, et al. Histopathological evaluation of orchiectomy specimens in 51 late postpubertal men with unilateral cryptorchidism. J Urol. 2014; 192(4): 1183-8.

11. Hack WW, Sijstermans K, van Dijk J, van der Voort-Doedens LM, de Kok ME, Hobbelt-Stoker MJ. Prevalence of acquired undescended testis in 6-year, 9-year and 13-year-old Dutch schoolboys. Arch Dis Child. 2007; 92(1): 17-20.

12. Guven A, Kogan BA. Undescended testis in older boys: further evidence that ascending testes are common. J Pediatr Surg. 2008; 43(9): 1700-4.

13. van der Plas EM, van Brakel J, Meij-de Vries A, de Muinck Keizer-Schrama SM, Hazebroek FW, Hack WW, et al. Acquired undescended testes and fertility potential: is orchiopexy at diagnosis better than awaiting spontaneous descent? Andrology. 2015; 3(4): 677-84.

14. Virtanen HE, Toppari J. Cryptorchidism and Fertility. Endocrinol Metab Clin North Am. 2015; 44(4): 751-60.
15. Kim SO, Na SW, Yu HS, Kwon D. Epididymal anomalies in boys with undescended testis or hydrocele: Significance of testicular location. BMC Urol. 2015; 15: 108.

16. Taskinen S, Wikström S. Effect of age at operation, location of testis and preoperative hormonal treatment on testicular growth after cryptorchidism. J Urol. 1997; 158(2): 471-3.

17. Kollin C, Granholm T, Nordenskjöld A, Ritzén EM. Growth of spontaneously descended and surgically treated testes during early childhood. Pediatrics. 2013; 131(4): e1174-80.

18. Durell J, Johal N, Burge D, Wheeler R, Griffiths M, Kitteringham L, et al. Testicular atrophy following paediatric primary orchidopexy: A prospective study. J Pediatr Urol. 2016; 12(4): 243.e1-4.

19. Carson JS, Cusick R, Mercer A, Ashley A, Abdessalam S, Raynor $\mathrm{S}$, et al. Undescended testes: does age at orchiopexy affect survival of the testis? J Pediatr Surg. 2014; 49(5): 770-3.

20. Lee PA, Coughlin MT, Bellinger MF. No relationship of testicular size at orchiopexy with fertility in men who previously had unilateral cryptorchidism. J Urol. 2001; 166(1): 236-9.

21. Noh PH, Cooper CS, Snyder HM, Zderic SA, Canning DA, Huff DS. Testicular volume does not predict germ cell count in patients with cryptorchidism. J Urol. 2000; 163(2): 593-6.

22. Ates F, Soydan H, Okçelik S, Çırakoglu A, Yılmaz I, Malkoç E, et al. Clinical and histopathological results of the adult patients with unilateral cryptorchidism. Turk J Urol. 2016; 42(2): 74-9.

23. van Brakel J, Kranse R, de Muinck Keizer-Schrama SM, Hendriks AE, de Jong FH, Bangma CH, et al. Fertility potential in men with a history of congenital undescended testes: a long-term follow-up study. Andrology. 2013; 1(1): 100-8.

24. Lee PA, Coughlin MT. Fertility after bilateral cryptorchidism. Evaluation by paternity, hormone, and semen data. Horm Res. 2001; 55(1): 28-32.

25. Thorup J, McLachlan R, Cortes D, Nation TR, Balic A, Southwell BR, et al. What is new in cryptorchidism and hypospadias--a critical review on the testicular dysgenesis hypothesis. J Pediatr Surg. 2010; 45(10): 2074-86.

26. Radmayr C, Dogan HS, Hoebeke P, Kocvara R, Nijman R, Stein $\mathrm{R}$, et al. Management of undescended testes: European Association of Urology/European Society for Paediatric Urology Guidelines. J Pediatr Urol. 2016; 12(6): 335-43. 